\title{
EXPERIMENTAL AND MODELING APPROACH FOR SOIL PHYSICAL DEGRADATION DUE TO DIFFERENT IRRIGATION TECHNIQUES
}

\author{
Uzair Shafqat $^{1}$, Abdul Nasir ${ }^{1, *}$, Syed Hamid Hussain Shah ${ }^{2}$, M. Mazhar Saeed ${ }^{3}$ and M. Usman \\ Farid $^{1}$ \\ ${ }^{1}$ Department of Structures and Environmental Engineering, University of Agriculture, Faisalabad, Pakistan; \\ ${ }^{2}$ Department of Irrigation and Drainage, University of Agriculture Faisalabad, Pakistan; ${ }^{3}$ Higher Education \\ Commission, Islamabad, Pakistan. \\ "Corresponding author's e-mail: anawan@uaf.edu.pk
}

\begin{abstract}
Pakistan is a country in which most of the area falls in arid or semi-arid regions. In arid zone, salinity is a serious and chronic problem for agriculture. Due to less rainfall we use different irrigation methods. In the recent era, water crisis is a major problem due to which people are moving towards modern water saving techniques e.g. high efficiency irrigation system (drip irrigation etc.). So, the present study was conducted in 2012-13 in order to analyze the effects of soil physical degradation by use of different irrigation techniques. Three different sites were selected; 1- Kota Wala near Sumundri, Faisalabad where drip irrigation system was installed in 2012, 2- Inter loop site near the Jaranwala, Faisalabad having drip irrigation installed in 2010, 3- Mamo Kangen, Faisalabad where drip irrigation system was installed at 2009 having old plastic mulching. For analyzing soil physical variations, 108 soil samples were collected at different soil depths $(0-90 \mathrm{~cm})$ from all sites. At each site, sample was collected under the drip and flood irrigation. Then the soil characteristics were checked by three different techniques, a) irrigation of land by drip system, b) drip irrigation with plastic mulching and c) flood irrigation system. Different soil physical and chemical parameters were measured including infiltration rate, bulk density, $\mathrm{pH}$, electrical conductivity (EC) and sodium absorption ratio (SAR). The results showed that the bulk density, EC, pH and SAR increased and infiltration rate decreased continuously under the drip irrigation technique. It was concluded that with proper management, plastic mulching was found to be a good practice to control the soil physical and chemical degradation.
\end{abstract}

Keywords: Electrical conductivity, sodium absorption ratio, flood irrigation, drip irrigation, arid zone.

\section{INTRODUCTION}

The total land of Pakistan is 79.6 million hectares (Mha) and about $70 \%$ lies in arid to semiarid zone. About $63.9 \%(50.88$ Mha) is lying on rangeland and $26.1 \%$ (22Mha) is culture able land, area of KPK and northern areas lie in humid to semiarid region. The Sindh province is lying completely in arid zone, Punjab and Baluchistan has arid to semi-arid ratio 58:29 and 43:57, respectively (PCRWR, 1999; Iqbal, et al. 2000). The two-third portion of Pakistan lies in semi-arid to arid zones according to report of Pakistan's agro climatic classification (Chaudhry et al., 2004). Due to shortage of fresh water the availability of water for irrigation purpose in arid zone is a major problem (Asma et al., 2012). However, significant uncertainties exist in determining irrigated areas which globally consume nearly $80 \%$ of all human water use. Total 6,685 to $7,500 \mathrm{~km}^{3} / \mathrm{yr}$ water is used by the agriculture land from which $4,586 \mathrm{~km}^{3} / \mathrm{yr}$ is by rain fed croplands and the rest by irrigated croplands (Thenkabail et al., 2009). Irrigated areas use about $2,099 \mathrm{~km}^{3} / \mathrm{yr}\left(1,180 \mathrm{~km}^{3} / \mathrm{yr}\right.$ of canal irrigation water and the rest is obtained from rain). However, 1.6 to 2.5 times of the irrigated water required by irrigated croplands is actually withdrawn from pumping of ground water, with an irrigation efficiency of 40-62\% (Thenkabail et al., 2009). It also reflects the increasing water shortage and soil degradation. In combination, these factors keep farmers for realizing the benefits of new technologies and thus undercut their incentive to adopt them (Nasir et al., 2016). By 2025, agriculture share of water from current situation will decrease from $70 \%-80 \%$ to $60 \%-70 \%$ due to increase of urbanization and diminishing water share (Eriyagama et al., 2009). Fresh water availability has direct link for fulfilling the crop water requirement along with crop production. Wheat demand in the developing countries will increase up to $60 \%$ in 2050 (Rosegrant and Agcoaili, 2010). On the other hand, climate change will decrease the wheat production by $20-30 \%$, it means overall production will be $66 \%$ (Easterling et al., 2007; Lobel et al., 2008; Rosegrant and Agcoaili, 2010). This decrease of wheat production is due to decreasing of water supply, soil fertility and threats from pests. Wheat production in Pakistan in rabi season decreased to $4.2 \%$ per hectare due to decrease in cropping area of wheat by $2.6 \%$ (PBS, 2010).

It is essential to introduce proper measurement techniques to ensure food security of the planet (Thenkabail et al., 2009). Wisely estimation of indicators must be identified which are harnessing the food security (Hussain et al., 2003). In the 
same way, world grain storages required for people are diminishing (FAO, 2009). Agriculture lands are decreasing and requirement per capita is increasing (Narayanamoorthy et al., 2007). Population of this world is increasing at a rate of 100 million/year (UNDP, 2009). In agricultural lands, salinity is also a serious threat for its production value (Khan et al., 2009).

In Pakistan, the soil affected by different levels of sodicity and salinity constitute 5.328 Mha out of which 50\% lies in Punjab, $40 \%$ in Sindh and 9\% in Baluchistan (Mian and Mirza, 1993). The latest surveys (2001-03) by SCARPs Monitoring Organization (SMO)-WAPDA indicate that $27 \%$ soils have surface salinity while $39 \%$ profile salinity problem in Pakistan (WRPO and IWASRI, 2005). Water logging, salinity and sodicity have reduced the drainage capacity of the soils resulting in lower soil fertility, decline in crop yields and loss of biodiversity. The salt-affected soils in irrigated and nonirrigated areas of Pakistan are about 6 Mha (Ghafoor et al., 2004).

Due to shortage of fresh water, farmers are adopting water saving techniques. From the total cultivable, land, $7 \%$ area is now irrigated through the drip irrigation (Alam et al., 2000). In the $7^{\text {th }}$ International Micro-Irrigation Congress in Kuala Lumpur, Malaysia, it was stated that Pakistan's 17.8 Mha land is covered by drip irrigation system (Reinders, 2002). Keeping in view the effects of soil salinity and sodicity, we are mainly interested in evaluating the degree of soil physical degradation under different irrigation methods/techniques.

\section{MATERIALS AND METHODS}

Composite soil samples were collected at different depths and spacing from dripper vertically and horizontally. The different soil depths were $0-15,15-30,30-45,45-60,60-75$ and 75-90 cm.

A standard procedure was adopted to evaluate the soil texture (ASTM D 422). An air dried soil sample weighing $50 \mathrm{~g}$ was taken. $1 \%$ sodium hexameta phosphate $\left(\mathrm{NaPO}_{5}\right)_{6}$ and $200 \mathrm{ml}$ of distilled water was added in soil sample. The solution was kept 24 hours and stir for 12 minutes with mechanical shaker. It was mixed with water to $900 \mathrm{ml}$ again and pour it $1000 \mathrm{ml}$ graduated cylinder. Hydro gauge and thermometer were into cylinder and two measurements were made after 5 minutes. Solution was stride for two hours, and two measurements were measured again. The following equations were used to measure sand, silt and clay ratios.

$\%($ silt + clay $) \quad=$ Reading after five minutes $\mathrm{CHR}_{1}$

$\%$ Clay $=$ Reading after two hours $\mathrm{CHR}_{2}$

$\%$ Silt $=\%$ (silt + clay $)-\%$ Clay

$\%$ Sand $=100-(\%$ Clay $+\%$ Silt $)$

Where, $\mathrm{CHR}_{1}=$ Corrected hydrometer reading after five minutes, $\mathrm{CHR}_{2}=$ Corrected hydrometer reading after two hours
After turning the sand, silt and clay percentages into International Textural Triangle, the soil textural class was determined. By using EC and $\mathrm{pH}$ meter, the $\mathrm{EC}$ and $\mathrm{pH}$ were measured after extracting the water from soil.

In order to evaluate the degree of soil physical degradation and soil hydraulic properties, water retention curves of each soil were determined by using water retention curves (RETC) computer program. The program may be used to fit several analytical models to observe water retention and/or unsaturated hydraulic conductivity data. The RETC code is a descendant of the SOHYP code previously documented by Van Genuchten (1978). As before, soil water retention data were described with the equations of Brooks and Corey (1964) and Van Genuchten (1980), whereas the pore-size distribution models of Burdine (1953) and Mualem (1976a) are used to predict the unsaturated hydraulic conductivity function. New features in RETC include (1) direct evaluation of the hydraulic functions when the model parameters are known, (2) more flexible choice of hydraulic parameters to be included in the parameter optimization process, and (3) the possibility of evaluating the model parameters from observed conductivity data rather than only from retention data, or simultaneously from measured retention and hydraulic conductivity data. Although the models used in RETC are intended to describe the unsaturated soil hydraulic properties for monotonic drying or wetting in homogeneous soils, the code can be easily modified to account for more complicated flow processes such as hysteretic two-phase flow (Lenhard et al., 1991) or preferential flow (Germann, 1990).

Carbonate and Bicarbonate $\left(\mathrm{CO}_{3}^{-2}+\mathrm{HCO}_{3}\right)$ : Saturation $\begin{array}{llllll}\text { extract was titrated against } & 0.01 & \mathrm{~N} & \mathrm{H}_{2} \mathrm{SO}_{4} & \text { using }\end{array}$ phenolphthalein indicators to colorless end point for $\mathrm{CO}_{3}{ }^{-2}$. To the same sample, methyl orange indicator was added and titrated against $0.01 \mathrm{~N} \mathrm{H}_{2} \mathrm{SO}_{4}$ to pinkish yellow end point for $\mathrm{HCO}_{3}^{-}$.

Calcium + Magnesium $\left(\mathrm{Ca}^{2+}+\mathbf{M g}^{2+}\right)$ : Saturation extract was titrated against $0.01 \mathrm{~N}$ EDTA (Versinate solution) in the presence of $\mathrm{NH}_{4} \mathrm{Cl}+\mathrm{NH}_{4} \mathrm{OH}$ buffer solution using Eriochrome black $\mathrm{T}$ indicator to a blue end point .

Sodium $\left(\mathrm{Na}^{+}\right)$: A series of $\mathrm{NaCl}$ standard solutions $(2,4,6,8$, $10,12,14$ and $16 \mathrm{ppm} \mathrm{Na}$ ) were used to standardize the Jenway PFP 7 Flame Photometer. Sample readings were recorded and converted to $\mathrm{ppm}$ from the graph prepared using instrument reading of the standard solutions.

Sodium adsorption ratio (SAR): Sodium absorption ratio was determined by the formula as:

$$
\mathrm{SAR}=\mathrm{Na} /[(\mathrm{Ca}+\mathrm{Mg}) / 2]^{1 / 2}
$$

Where, the concentration of soluble cations is in $\mathrm{mmol}_{\mathrm{c}} \mathrm{L}^{-1}$.

\section{RESULTS AND DISCUSSION}

The graphical representation shows that the value of SAR increases by drip irrigation compared to flood irrigation (Fig. 1). The first six observations in the graph show the SAR 
values for flood irrigation and the remaining show the SAR values for drip irrigation. The magnitude of SAR in first two years is relatively more significant in drip irrigation compared to flood irrigation, whereas in $3^{\text {rd }}$ year, there was no significant difference in both drip and flood. The reason is that salts do not leach down into the root zone due to limited soil moisture under drip irrigation compared to flood irrigation, whereas the salts leach down from the root zone due to the greater magnitude of leaching fraction.

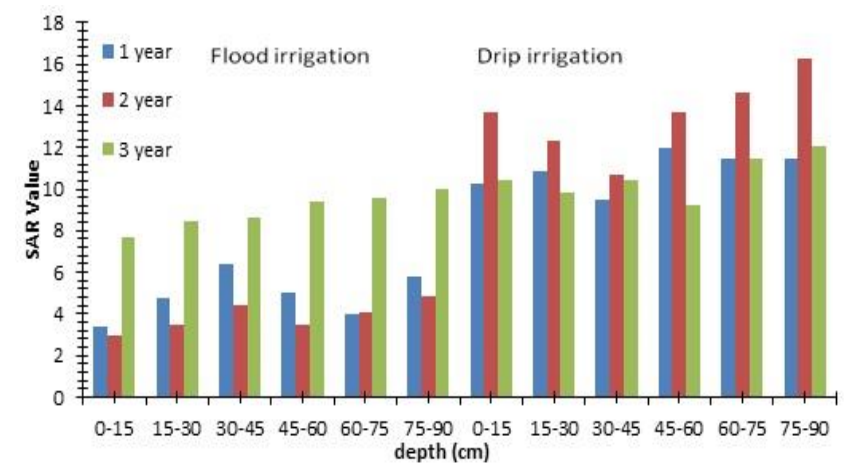

Figure 1. The plot of the magnitude of $S A R$ as a function of root zone depth under three years for flood irrigation and drip irrigation.

Figure 2 shows that the value of EC increased in drip irrigation as compared to flood irrigation. In first two years data, there was a significant difference in the value of EC in drip and flood irrigation. This is due to salts accumulation under drip irrigation system.

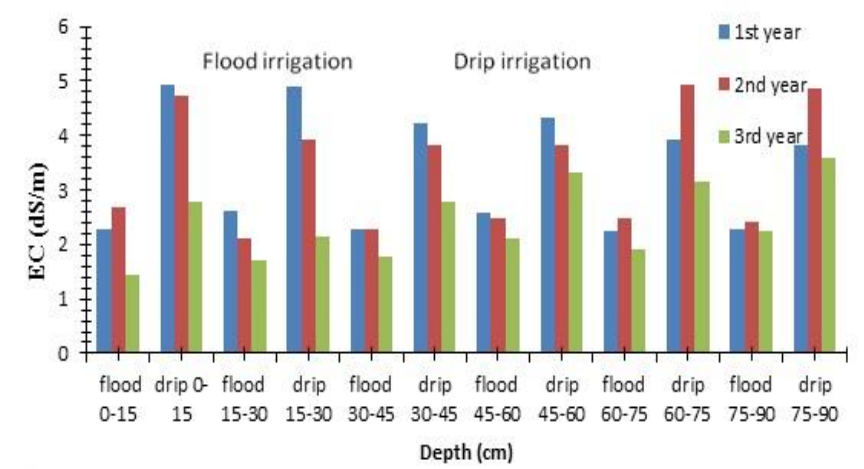

Figure 2. The plot of the magnitude of EC as a function of root zone depth under three years for flood and drip irrigation.

Figure 3 shows clearly that the value of $\mathrm{pH}$ in drip irrigation method was higher due to salts accumulation under the drip irrigation and the $\mathrm{pH}$ value was low in flood irrigation because salts were leached down due to an excessive amount of water.

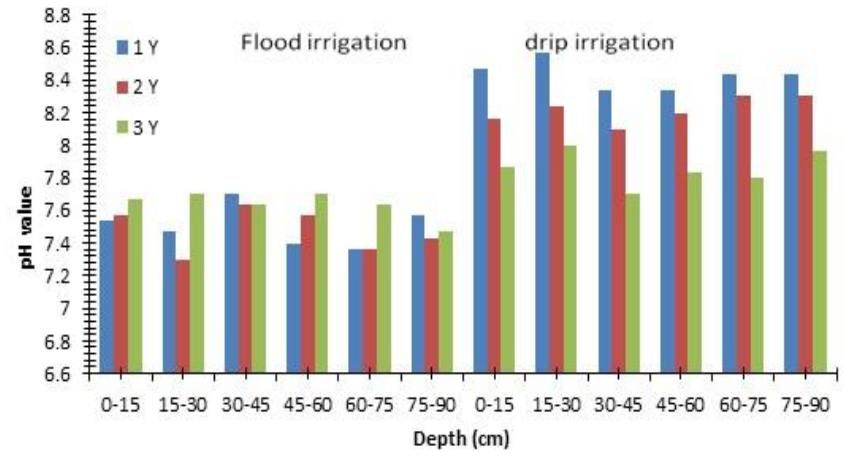

Figure 3. The plot of the magnitude of $\mathrm{pH}$ as a function of root zone depth under three years for flood and drip irrigation.

The infiltration rate of water at different depths in both the techniques decreased continuously due to accumulation of salts in a bulk quantity.

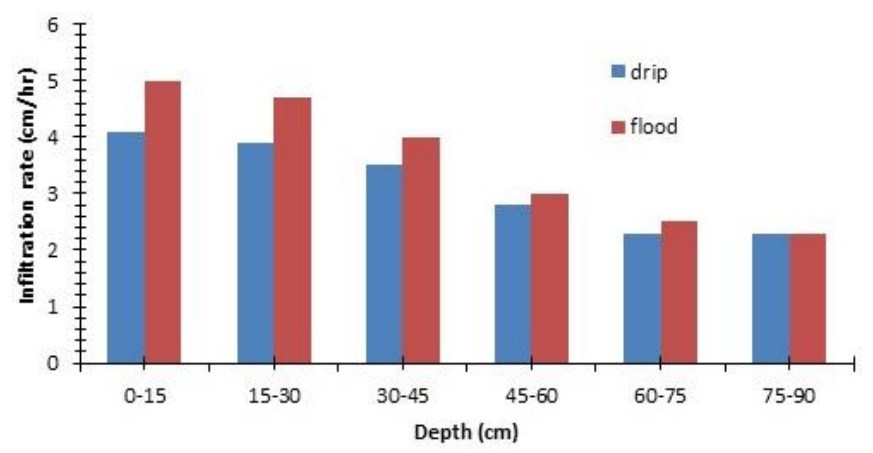

Figure 4. The plot of the magnitude of infiltration rate as a function of root zone depth for flood and drip irrigation.

The bulk density of the upper layer of soil was more than the lower layer (Fig. 5). The graph shows that bulk density is high due to small soil pores and high salt contents.

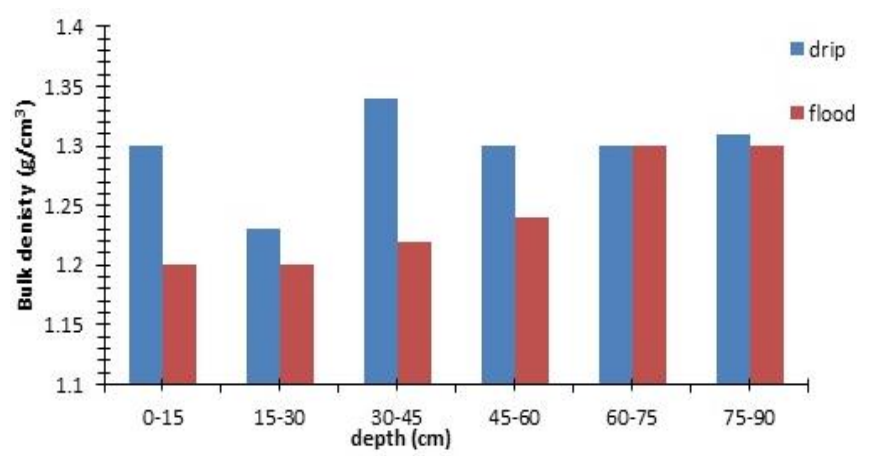

Figure 5. The plot of the magnitude of bulk density as a function of root zone depth for flood and drip irrigation. 


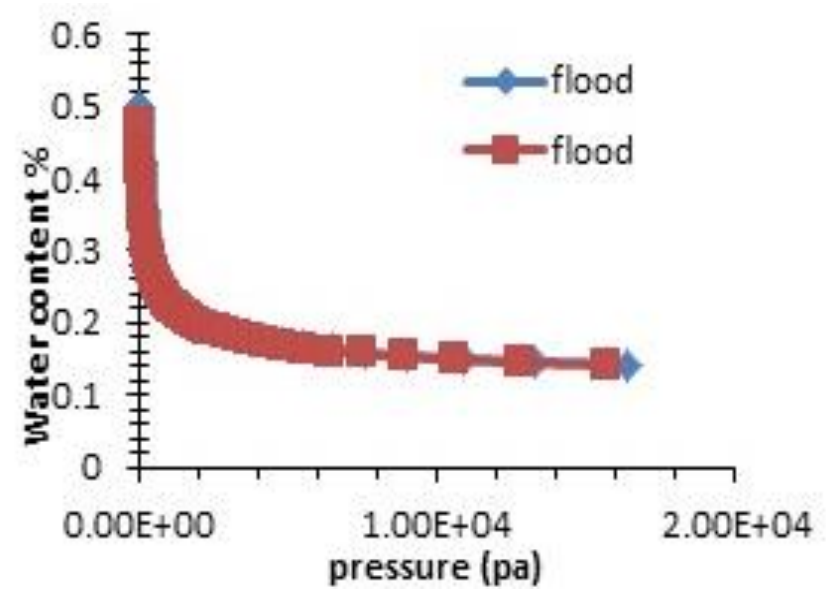

Figure 6. The plot of the magnitude of water water content as a function of $0-15 \mathrm{~cm}$ soil depth.

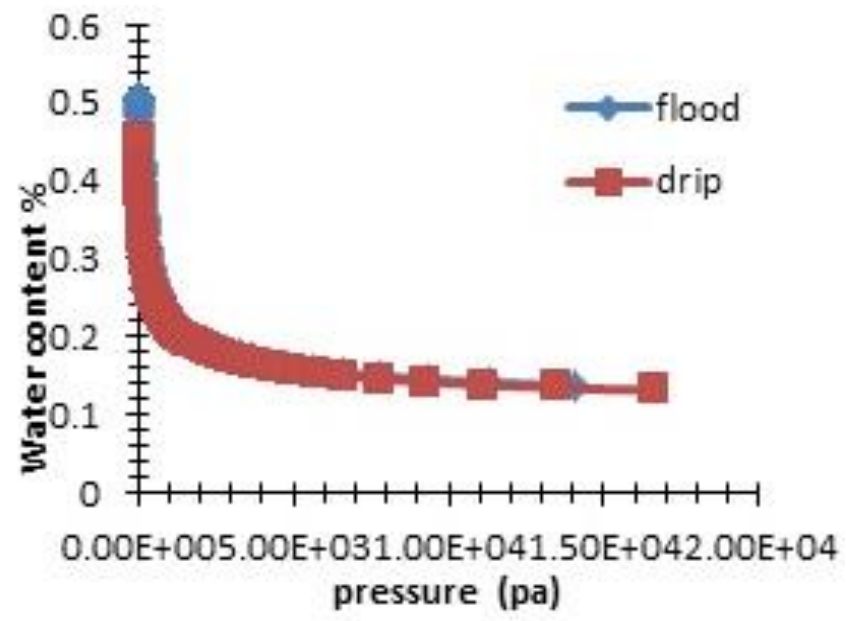

Figure 7. The plot of the magnitude of content as a function of $15-30 \mathrm{~cm}$ soil depth.

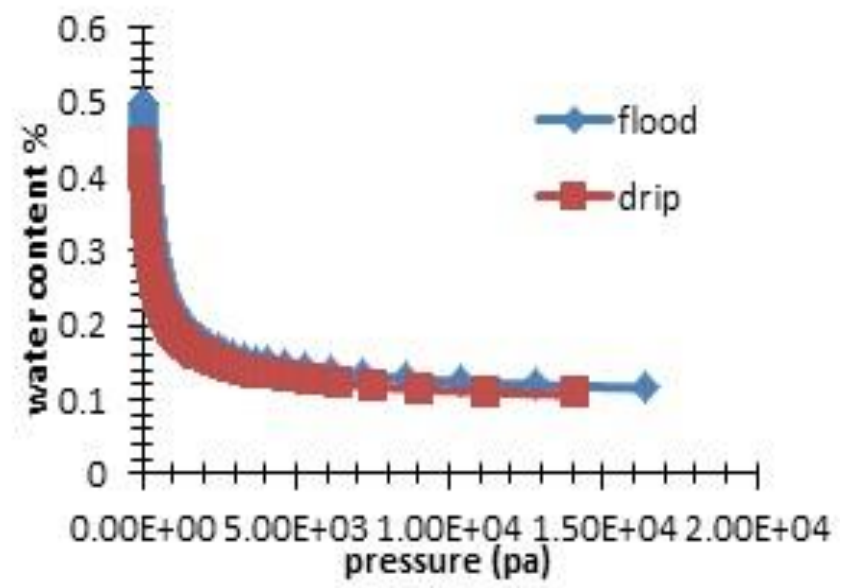

Figure 8. The plot of magnitude of water content as function of 0-15 cm soil depth.

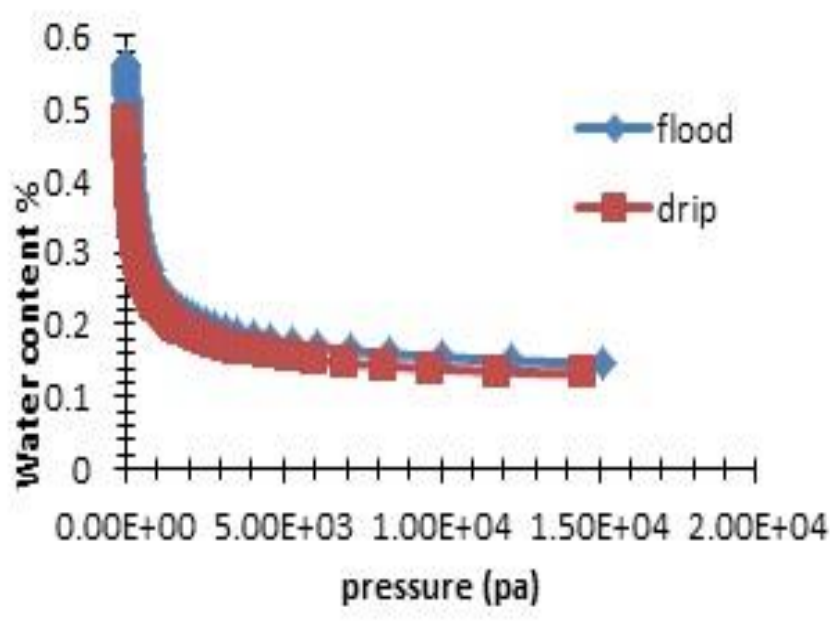

Figure 9. The plot of magnitude of water content as function of $15-30 \mathrm{~cm}$ soil depth.

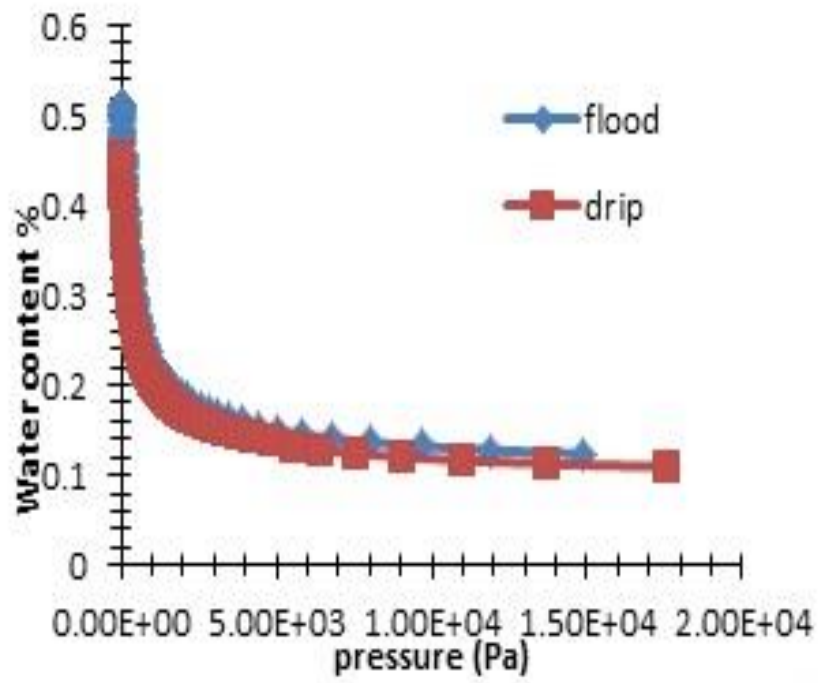

Figure 10. The plot of the magnitude of water content as a function of $60-75 \mathrm{~cm}$ soil depth.

The graph (Fig. 6-10) were made by using RETC software which shows water movement in flood and drip irrigation under different suction pressure heads.

Variation in infiltration rate under different depths: Three years infiltration rate under flood and drip irrigation systems showed that infiltration rate was more under the flood irrigation as compared to drip irrigation. Figure 11 shows that infiltration rate of one year under drip and flood irrigation at different depths from 0 to $90 \mathrm{~cm}$.

Figure 13 shows infiltration rate trend of three years old drip irrigation system installed site and there was a significant difference between first three reading of flood irrigation and drip irrigation. The reason is that the salt accumulates more in the upper layer of soil. 


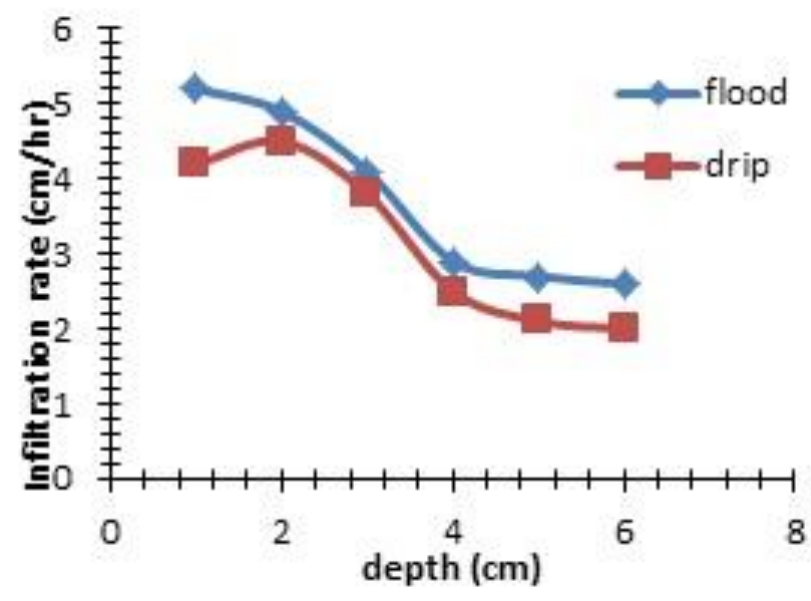

Figure 11. The plot of the magnitude of water content as a function of soil depth. function of soil depth.

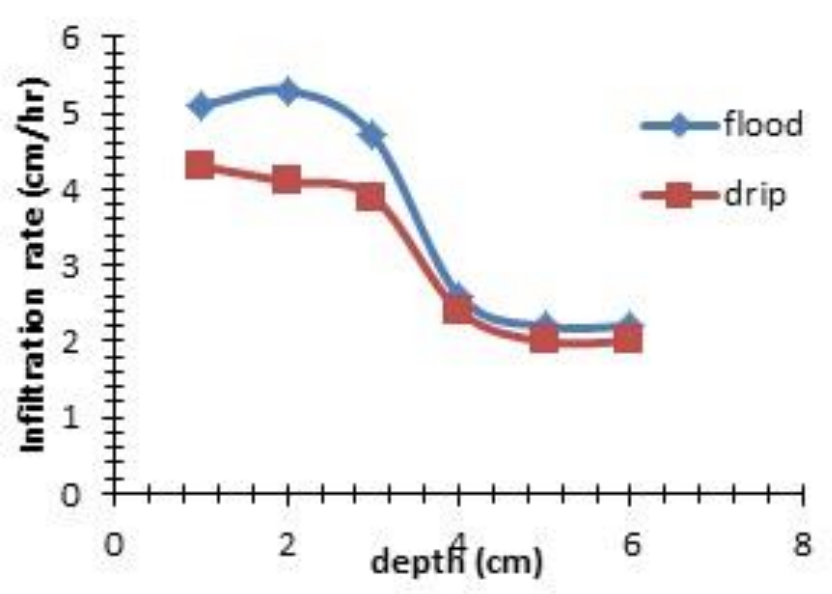

Figure 12. The plot of the magnitude of water content as a function of soil depth.

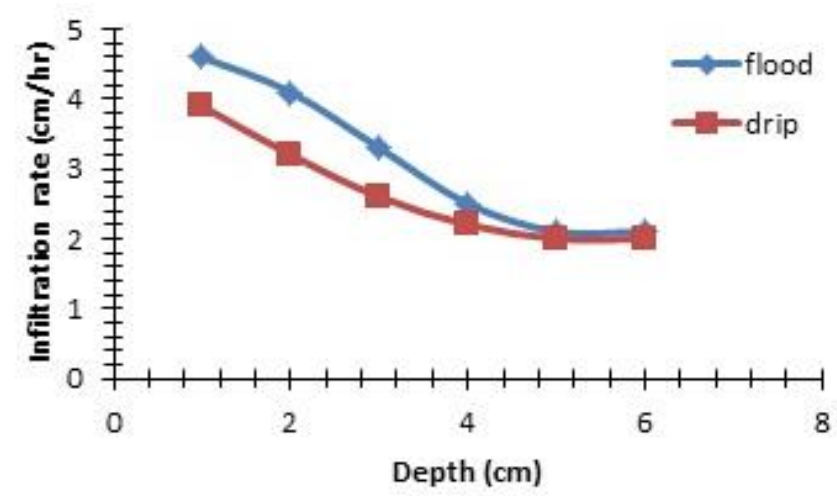

Figure 13. The plot of the magnitude of water content as a function of soil depth.
Conclusions: Different irrigation techniques were evaluated to determine the degree of physical degradation soil in terms of bulk density, EC, SAR, pH and infiltration rate. It was observed that all the study parameters, including bulk density, $\mathrm{EC}, \mathrm{SAR}$ and $\mathrm{pH}$, increased with time by using drip irrigation in comparison to flood irrigation. While on the other side the Infiltration rate was in excess for flood irrigation to drip irrigation however it gradually decreased and become equal to drip irrigation with increasing depth of root zone. Thus it concluded a reduced impact on the infiltration rate due to drip irrigation particularly at higher root zones. As a matter of fact, it depicts the effect of plastic mulching which, along with drip irrigation changed the infiltration rate. Water content as a major parameter showed a clear decrease trending along the duration i.e. for 3 years, for drip irrigation in comparison to flood irrigation. However, this decreasing trend is much obvious in upper root zones as compared to deeper depths. Therefore, with proper management, plastic mulching was found to be good practice to control soil physical degradation.

\section{REFERENCES}

Alam, M., A., M.N. Bhutta and A.H. Azhar. 2000. Use and limitations of sprinkler and drip irrigation systems in Pakistan. Pak. J. Agri. Sci. 12:156-163.

Asma, S., C. Arslan, A. Nasir and A. Khan. 2012. Physical analysis of groundwater at thickly populated area of Faisalabad by using GIS. Pak. J. Agri. Sci. 49:541-547.

ASTM 422-63. 2007. Standard test method for particle-size analysis of soils. Available online at www.astm.org/Standards/D422

Chaudhry, Q.Z. and G. Rasul. 2004. Agro-climatic classification of Pakistan. Quart. Sci. Vision 9:59-66.

Eastriling, W.E., P.K. Aggrawal, P. Batima, K.M. Brander, L. Erada, S.M. Howden, A. Kirilenko, J. Morton, J.F. Soussana, J. Schmidhuber and F.N. Tubiello. 2007. Food, fiber and forest product: In. M.L. Parry, O.F. Canziani, J.P. Palutikof, P.J. Van der Liden and C.E. Hanson (eds.), Climate Change 2007: Impact, adoption and vulnerability. Contribution of working group II to the fourth assessment report of intergovermental panel on climate change. Multi location testing to identify plant response 137. Cambridge University Prees, Cambridge, UK, pp.273-313.

FAO. 2009. Food Outlook: Outlook Global Market Analysis, FAO: Rome, Italy.

Germann, P.F. 1990. Preferential flow and the generation of run-off. Boundary Layer Flow Theory. Water Resou. Res. 26:3055-3063.

Ghafoor, A., M. Qadir. and G. Murtaza. 2004. Salt-affected soils: Principles of management. A Book Published by Allied Book Center, Urdu Bazar, Lahore. pp 304. 
Hussain, I. and M.A. Hanjra. 2003. Does irrigation water matter for rural poverty alleviation? Evidence from South and South-East Asia. Water Policy 5:429-442.

Iqbal, M., U. Farooq, A. Bashir, N.A. Khan and S.Z. Malik. 2000. A Baseline survey for the development of livestock sector in Cholistan. Joint Publication of AERU, AARI, Faisalabad, SSI, NARC, Islamabad and GTZ, Lahore, Pakistan.

Khan, S. and M.A. Hanjra. 2009. Footprints of water and energy inputs in food production- Global perspectives. Food Policy 34:130-140.

Lenhard, R.J., J.C. Parker and J.J. Kaluarachchi. 1991. Comparing simulated and experimental hysteretic twophase transient fluid flow phenomena. Water Resour. Res. 27:2113-2124.

Lobel, D.B., M.B. Burke, C. Tebaldi, M.D. Mastrqndrea, W.P. Falcon and R.L Naylor. 2008. Supporting online material for: prioritizing climate change adoption need for food security in 2030. DOI 10.1126/science.1152339.

Mian, A. and M.Y.J. Mirza. 1993. Pakistan's soil resources. A joint publication of IUCN and the Environment and Urban Affairs Division of the Government of Pakistan (Pakistan National Conservation Strategy Sector Paper No. 4.)

Mualem, Y. 1976a. A new model for predicting the hydraulic conductivity of unsaturated porous media. Water Resour. Res. 12:513-522.

Narayanamoorthy, A. 2007. Deceleration in agricultural growth: technology fatigue or policy fatigue? Econ. Polit. Weekly 42: 2375-2379.

Nasir. A., M.S.Nasir, I.Shauket, S.Anwar and I.Ayub. 2016. Impact of Samundari Drain on water resources of Faisalabad City. Advances in Environmental Biology. 10(1):155-160

PBS. 2010. Punjab Development Statistics. Punjab Bureau of Statistics, Government of the Punjab, Lahore, Pakistan.
PCRWR. 1999. Information Booklet. Pakistan Council of Research in Water Resources. Regional Office, Bahawalpur, Pakistan.

Reinders. F.B. 2002. Micro-irrigation: world overview on technology and utilization. Key note address at the opening of the $7^{\text {th }}$ International Micro-Irrigation Congress in Kuala Lumpur, Malaysia.

Rosegrant, M.W. and M. Agcoaili. 2010. Global food demand, supply and price perspective. International Food Policy Research Institute, Washington, D.C., USA.

Thenkabail, P.S., G.J. Lyon, H. Turral and C. M.Biradar. 2009. Remote sensing of global croplands for food security; CRC Press-Taylor and Francis Group: Boca Raton, London, UK, p.556.

Van der Zee, S.E.A.T.M., S.H.H. Shah, C.G.R. Van Uffelen, P.A.C. Raats, and N. dal Ferro. 2010. Soil sodicity as a result of periodical drought, Agric. Water Manage. 97:41-49.

Van Genuchten, M.Th. 1978. Calculating the unsaturated hydraulic conductivity with a new closed-form' analytical model. Research Report 78-WR-08. Dept. of Civil Engineering, Princeton Univ., Princeton, New Jersey; p.63.

Van Genuchten, M.Th. 1980. A closed-form equation for predicting the hydraulic conductivity of unsaturated soils. Soil Sci. Soc. Am. J. 44:892-898.

Wild, A. 2003. Soils, land and food: Managing the land during the twenty-first century. Cambridge, UK: Cambridge University Press.

WRPO and IWASRI. 2005. 2005. Drainage Master Plan of Pakistan; Volume II Main Report. UNDP Human Development Mobility and Water Resources Planning Organization and International Water logging \& Salinity Research Institute, Pakistan. 